Article

\title{
The Multi-Wavelength Absorption Analyzer (MWAA) Model as a Tool for Source and Component Apportionment Based on Aerosol Absorption Properties: Application to Samples Collected in Different Environments
}

\author{
Vera Bernardoni ${ }^{1}$ (D), Rosaria Erika Pileci ${ }^{1,+}{ }^{\text {, }}$ Lorenzo Caponi $^{2}$ and Dario Massabò ${ }^{3, *}$ \\ 1 Department of Physics, Università degli Studi di Milano and INFN-Milan, Via Celoria 16, 20133, Milan, Italy; \\ vera.bernardoni@unimi.it (V.B.); rosaria.pileci@psi.ch (R.E.P.) \\ 2 PM_TEN s.r.l., piazza della Vittoria 7/14, 16121 Genova, Italy; lorenzo.caponi@pm10-ambiente.it \\ 3 Department of Physics and INFN, University of Genoa, via Dodecaneso 33, 16146 Genova, Italy \\ * Correspondence: massabo@ge.infn.it; Tel.: +39-010-353-6325 \\ $\dagger$ now at: Laboratory of Atmospheric Chemistry (LAC), Paul Scherrer Institut (PSI), Aarebrücke, \\ 5232 Villigen, Switzerland.
}

Received: 15 October 2017; Accepted: 7 November 2017; Published: 13 November 2017

\begin{abstract}
The multi-wavelength absorption analyzer model (MWAA model) was recently proposed to provide a source (fossil fuel combustion vs. wood burning) and a component (black carbon BC vs. brown carbon $\mathrm{BrC}$ ) apportionment of $\mathrm{b}_{\mathrm{abs}}$ measured at different wavelengths, and to provide the $\mathrm{BrC}$ Ångström Absorption exponent $\left(\alpha_{\mathrm{BrC}}\right)$. This paper shows MWAA model performances and issues when applied to samples impacted by different sources. To this aim, the MWAA model was run on samples collected at a rural (Propata) and an urban (Milan) site in Italy during the winter period. Lower uncertainties on $\alpha_{\mathrm{BrC}}$ and a better correlation of the $\mathrm{BrC}$ absorption coefficient $\left(b_{\mathrm{abs}}{ }^{\mathrm{BrC}}\right.$ ) with levoglucosan (tracer for wood burning) were obtained in Propata (compared to Milan). Nevertheless, the correlation previously mentioned improved, especially in Milan, when providing a priori information on $\alpha_{\mathrm{BrC}}$ to MWAA. Possible reasons for this improvement could be the more complex mixture of sources present in Milan and the aging processes, which can affect aerosol composition, particle mixing, and size distribution. OC and EC source apportionment showed that wood burning was the dominating contributor to the carbonaceous fractions in Propata, whereas a more complex situation was detected in Milan. Simultaneous $b_{a b s}(B C)$ apportionment and EC measurements allowed MAC determination, which gave analogous results at the two sites.
\end{abstract}

Keywords: Multi-Wavelength Absorption Analyzer model; optical component apportionment; optical source apportionment; aerosol absorption coefficient; polar photometer; brown carbon; black carbon; Ångström Absorption exponent; light absorption; optical measurements of particle-loaded filters

\section{Introduction}

Scattering and absorption properties of atmospheric aerosol are directly responsible for aerosol-radiation interactions. In particular, aerosol light absorption provides a positive contribution to the Earth radiation balance. In addition to the aerosol-radiation effects, absorbing aerosol immersed in cloud droplets absorbs light and facilitates water evaporation and cloud dispersion, an additional indirect effect that counteracts the cooling effect of cloud droplet nucleation [1]. Among absorbing species, the black carbon (BC) is the main global-warming contributor in atmospheric 
aerosol. Nevertheless, great uncertainties (about 1 order of magnitude) are still associated with the estimates of its radiative forcing contribution. They are mainly related to difficulties in assessing BC spatial-temporal distribution and in the evaluation of the effects of the mixing state on BC optical properties $[1,2]$.

Pure BC is assumed to have an imaginary part of the refractive index independent of the wavelength $(\lambda)$. Thus, for pure BC small spheres the expected $\lambda$-dependence of the BC absorption coefficient is $b_{a b s}{ }^{B C}(\lambda) \sim \lambda^{-1}$ (e.g., [3]). In the past, $B C$ and mineral dust were considered as the only light-absorbing components in the atmospheric aerosol. In the last decade, another aerosol component-the brown carbon $(\mathrm{BrC})[4]$ - has been evidenced as a further contributor to absorption. $\mathrm{BrC}$ is composed of organic material that weakly absorbs radiation at long visible wavelengths but with enhanced absorption behavior towards short wavelengths. Its absorption characteristics can, in principle, provide a positive contribution to the Earth radiation balance both as pure material and modifying BC absorption characteristics by mixing effects (see e.g., [5,6]), but the extent of these effects is still under debate $[7,8]$. Indeed, inconsistencies between theoretical/laboratory tests and in-field observations were reported ([9] and therein cited literature). For this reason, most climate modeling approaches currently do not include possible effects related to $\mathrm{BC}$ and $\mathrm{BrC}$ mixing $[9,10]$.

$\mathrm{BrC}$ is still poorly characterized due to its chemical complexity (affecting also optical properties) and unclear emission sources and formation processes. Compounds contributing to $\mathrm{BrC}$ were reported to span from extremely low volatility compounds (ELVOC)—e.g., Humic-Like Substances (HULIS)— to much more volatile compounds related to secondary organic aerosol (SOA) ([9] and therein-cited literature), even if the contribution to absorption seems to be dominated by ELVOC [11,12]. Also, BrC source emissions merit further investigation: wood burning has been identified as an important primary $\mathrm{BrC}$ source (e.g., [11,13-15]). Recently, other possible sources of $\mathrm{BrC}$ have been reported, e.g., biogenic contributions, $\mathrm{BrC}$ formation due to secondary processes [9], and possible $\mathrm{BrC}$ emissions by gasoline vehicles [16] or coal combustion [17]. Nevertheless, $\mathrm{BrC}$ sources other than wood burning are generally neglected in optical source apportionment approaches (e.g., [18-21]). Also BrC light-absorption properties need further investigation. Indeed, the chemical complexity of $\mathrm{BrC}$ affects its optical behavior. For example, an increase of light absorption potential at increasing molecular weight was reported [12,22]. Furthermore, the combustion efficiency and photochemical or aging processes affect $\mathrm{BrC}$ optical properties [23]. Despite all these issues, attempts of including $\mathrm{BrC}$ in climate models are developing in recent years ([24] and therein-cited literature).

It is noteworthy that several studies on $\mathrm{BrC}$ absorption properties and mass absorption coefficient were carried out after $\mathrm{BrC}$ extraction in water or solvents (see e.g., [15,25-31]). Nevertheless, particle optical properties-even for homogeneous particles-depend on particle size and shape in the atmosphere (see e.g., [32]), which can be different from the properties of bulk or extracted material. To provide more robust information on the properties of $\mathrm{BrC}$-containing particles, studies carried out on bulk/extracted material can be coupled to optical models (e.g., by Mie theory or the core-shell model), but also in this case assumptions, e.g., on particle size and mixing state, are needed (see, e.g., [31]). Thus, it is important to carry out studies aimed at providing information on $\mathrm{BrC}$ absorption characteristics minimizing the sample pre-treatment.

Moving in the previous frame, source apportionment models based on multi- $\lambda$ measurements of the aerosol absorption coefficient $\left(b_{\mathrm{abs}}(\lambda)\right)$, determined on aerosol collected on filter with no further treatments, were proposed in the literature (i.e., the Aethalometer model [18] and the Multi-Wavelength Absorption Analyzer model (MWAA model) [20]). The Aethalometer model is a widespread model providing information on source contributions by fossil fuel combustion (FF) and wood burning (WB). It is based on assumptions about the Ångström absorption exponent $(\alpha)$ of the two sources. As a step forward, Massabò et al. [20] proposed the MWAA model to provide not only a source (FF and WB) but also a component (BC and $\mathrm{BrC})$ apportionment of $\mathrm{b}_{\mathrm{abs}}(\lambda)$. Furthermore, the MWAA model can provide information on $\alpha$ for $\operatorname{BrC}\left(\alpha_{\mathrm{BrC}}\right)$. 
Massabò et al. [20] applied the MWAA model to multi- $\lambda b_{a b s}(\lambda)$ data measured off-line by laboratory instrumentation (Multi-Wavelength Absorption Analyzer [20,33]). Nevertheless, the model can be applied to any $b_{a b s}(\lambda)$ data, provided that at least $4-\lambda$ measurements are performed. For example, off-line measurements performed by the polar photometer PP_UniMI $[34,35]$ or on-line Aethalometer measurements (properly corrected) [36] can be other possible inputs to the MWAA model. The $b_{a b s}(\lambda)$ measurements carried out by such instruments do not require any sample treatment after particle collection. Thus, it is expected that the $\alpha_{\mathrm{BrC}}$ information provided by the MWAA model on such data represents the $\mathrm{BrC}$ optical absorption behavior in atmosphere better than measurements carried out after $\mathrm{BrC}$ water/solvent extraction - even if re-arrangement of $\mathrm{BrC}$ material on filter fibers cannot be excluded [37].

In this work, a comparison is performed between the MWAA model performances on PM10 (i.e., particles with an aerodynamic diameter lower than $10 \mu \mathrm{m}$ ) datasets collected at sites with different characteristics. The first dataset was collected at a rural background site in the Italian Appennines. The second dataset was collected at an urban background site in Milan (Italy). In the paper, we evidence merits and issues of the application of the MWAA model at the two sites.

\section{Experiments}

\subsection{Sites and Sampling}

The data reported in this manuscript are referred to two different campaigns.

The first campaign was performed in Propata, a rural site in Italy. Propata is a small village (less than 150 inhabitants) at $990 \mathrm{~m}$ a.s.l. in the Ligurian Appennines. During wintertime, low temperatures are usually reached and wood burning is extensively used for domestic heating and cooking [20,33,38]. PM10 samples were collected on pre-fired $\left(700{ }^{\circ} \mathrm{C}, 1-\mathrm{h}\right)$ quartz-fiber filters $(47 \mathrm{~mm}$ diameter, 2500QAO-UP, Pall) using a low-volume sampler (flow-rate $2.3 \mathrm{~m}^{3} / \mathrm{h}$, European inlet compliant with the EN-12341 norm). Sampling duration was 48-h from midnight to midnight. Aerosol sampling was performed between 7th November 2014 and 7th January 2015. Twenty-eight PM10 samples were available in total.

The second sampling campaign was performed in Milan (Italy) at an urban background site placed on the roof (about $10 \mathrm{~m}$ a.g.l.) of the Department of Physics of the University of Milan. Milan is situated in the Po Valley, which is one of the main hot-spot pollution areas in Europe. For this reason, different source apportionment studies by receptor models based on chemical characterization were carried out in the last decade on integrated aerosol size-fractions (e.g., [39-42]) and on suitably characterized [43] size-segregated samples [44]. These works evidenced that the site is impacted by a complex mixture of sources; traffic (both exhaust and non-exhaust), wood burning, re-suspended dust, and industry were identified as the main primary sources, but secondary compounds play a key role in explaining the total measured mass. The influence of particle aging processes and the impact of both local and regional contributions were identified in the size-segregated study [44]. PM10 samples were collected on pre-fired quartz fiber filters (same filter type and treatment as in Propata) using an EPA inlet operating at $1 \mathrm{~m}^{3} / \mathrm{h}$. Twenty-eight samples with 12-h resolution (9-21 or 21-9) were collected in the period 21 November-21 December 2016.

\subsection{Aerosol Absorption Coefficient Measurements by the MWAA Instrument and PP_UniMI}

The Multi-Wavelength Absorption Analyzer (MWAA) instrument [20,33] and the polar photometer PP_UniMI $[34,35]$ are multi-wavelength devices providing $b_{\text {abs }}(\lambda)$ measurements of aerosol collected on filters. The $b_{a b s}(\lambda)$ measurements are performed at $375,407,532,635$, and $850 \mathrm{~nm}$ by MWAA [20], and at 405, 532, 635, $780 \mathrm{~nm}$ by PP_UniMI [35].

The MWAA and PP_UniMI instruments measure the total light transmitted and diffused in the front and back hemispheres by blank and loaded filters. To obtain $b_{a b s}(\lambda)$ from these measurements, multiple scattering between the layer containing the aerosol and the filter has to be properly considered. 
To this aim, the radiative transfer model proposed by Hänel $[45,46]$ for polycarbonate filters and extended by Petzold and Schönlinner [47] to fiber filters was applied. Briefly, the model inputs are the total light scattered in the front and back hemispheres by blank and loaded filters. The sample is modelled into two layers, one containing aerosol (aerosol-filter layer) and the other composed by the filter matrix only. All interactions between the aerosol-filter layer and the filter matrix are considered. The model outputs are the single scattering albedo $(\omega)$ and the optical depth $(\tau)$ of the aerosol-filter layer. As the absorption contribution is related to aerosol only, the absorbance (ABS) of the deposited aerosol can be evaluated as ABS $=(1-\omega) \cdot \tau$. Sampling volume $(V)$ and deposit area (A) can be then exploited to retrieve the aerosol absorption coefficient in air. It is noteworthy that-opposite to instrumentation based on transmitted light only-the simultaneous measurements of transmitted and scattered light avoid the need for correction algorithms to account for the scattering properties of the aerosol and/or of parallel measurements of the scattering coefficient.

The MWAA instrument and PP_UniMI differ in their ways of assessing the total light scattered in the front and back hemispheres. Indeed, the MWAA instrument applies the same approach presented in Petzold and Schönlinner [47]: information on light diffused at fixed angles is used-together with assumptions on the shape of the phase function for aerosol collected on fiber filters-to provide the total scattered light by analytical functions. On the contrary, PP_UniMI performs angular-resolved measurements with about $0.4^{\circ}$ resolution in the range $0-173^{\circ}$. Then, the total amounts of the light diffused in the forward and back hemispheres are evaluated by solid angle integration. This allows PP_UniMI to operate also on aerosol collected on other filter matrices (e.g., membrane filters, see [35]) with no need for external information on the phase function shape. Assumptions on the phase function shape are needed only for extrapolating values in the range $173-180^{\circ}$.

The Milan dataset was analyzed both by the MWAA instrument and PP_UniMI for sake of comparison. Scatterplots of MWAA and PP_UniMI measurements at comparable wavelengths (i.e., $635 \mathrm{~nm}, 532 \mathrm{~nm}$, and $407 / 405 \mathrm{~nm}$ ) are reported in Figure 1. Deming regression was performed as measurement uncertainties are comparable between the two instruments (about 10\%). It is noteworthy that all regression line slopes were compatible to 1 and intercepts were compatible to 0 for significant level of 0.02 . Furthermore, measurements were very well correlated with correlation coefficient $R>0.98$ at all wavelengths.

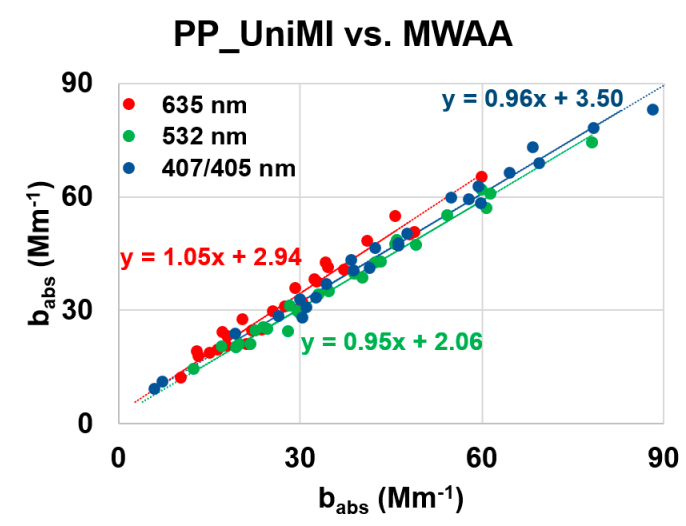

Figure 1. Scatterplot of the polar photometer PP_UniMI vs. Multi-Wavelength Absorption Analyzer (MWAA) measurements at comparable wavelengths. Deming regression lines are also represented. $\mathrm{R}>0.98$ was found in all cases. Please note that the MWAA instrument operates at $407 \mathrm{~nm}$, whereas PP_UniMI operates at $405 \mathrm{~nm}$ for what concerns the blue light.

\subsection{Chemical Characterization}

After being analyzed with the MWAA instrument (and PP_UniMI in the case of Milan samples only), one punch $\left(1.5 \mathrm{~cm}^{2}\right)$ of each filter was extracted by sonication (1-h) using $5 \mathrm{~mL}$ ultrapure (Milli-Q) water. The extract was analyzed to determine levoglucosan concentration by High-Performance Anion 
Liquid Chromatography coupled with Pulsed Amperometric Detection (HPAEC-PAD) following the procedure described in [48]. Minimum detection limit is about $2 \mathrm{ng} / \mathrm{mL}$ (i.e., $0.7 \mathrm{ng} / \mathrm{m}^{3}$ in Propata and $6.6 \mathrm{ng} / \mathrm{m}^{3}$ in Milan, due to different sampling conditions) and uncertainties are about $11 \%$.

For the determination of the carbonaceous fraction, a second filter punch $\left(1.0 \mathrm{~cm}^{2}\right)$ of each filter was analyzed by a Thermal Optical transmittance (TOT) instrument (Sunset Laboratory Inc.). Propata samples were analyzed following the EUSAAR_2 protocol [49], while a NIOSH-like protocol (He_870) [50] has been used in the case of the Milan samples. This choice has been taken to have continuity with previous respective measurement campaigns. Minimum detection limit is $0.15 \mu \mathrm{g}$ carbon, corresponding to $0.02 \mu \mathrm{g} / \mathrm{m}^{3}$ in Propata and $0.15 \mu \mathrm{g} / \mathrm{m}^{3}$ in Milan due to different sampling conditions. Analytical uncertainties were about $10-15 \%$ depending on the carbon fraction.

\subsection{Optical Source and Component Apportionment: The Multi-Wavelength Absorption Analyzer Model}

In this work, the optical approach known as Multi-Wavelength Absorption Analyzer model (MWAA model) was applied to perform source and component apportionment of $b_{a b s}(\lambda)$ and carbonaceous fractions (OC and EC). The detailed description of the model bases can be found elsewhere [20]. In the following paragraphs, only the summary of the main steps necessary for the apportionment will be recalled.

\subsubsection{Aerosol Absorption Coefficient Apportionment}

The MWAA model requires $b_{a b s}(\lambda)$ as input, at least at $4 \lambda$ s. The final outputs are the $b_{a b s}(\lambda)$ contributions due to $\mathrm{BC}$ by fossil fuel combustion, $\mathrm{BC}$ by wood burning, and $\mathrm{BrC}$ (i.e., $\mathrm{b}_{\mathrm{abs}, \mathrm{FF}}{ }^{\mathrm{BC}}(\lambda)$, $b_{a b s, W B}{ }^{B C}(\lambda)$, and $b_{a b s}{ }^{B C}(\lambda)$, respectively), as well as information on $\alpha_{B r C}$.

The model starts from the following assumptions for component apportionment:

(a) $\mathrm{BC}$ and $\mathrm{BrC}$ are the only light-absorbing species in the aerosol sample, i.e., $\mathrm{b}_{\mathrm{abs}}(\lambda)=\mathrm{b}_{\mathrm{abs}}{ }^{\mathrm{BC}}(\lambda)+$ $b_{a b s}{ }^{B r C}(\lambda)$, where $b_{a b s}{ }^{B C}(\lambda)$ is the absorption coefficient due to the whole $B C$ in the sample-with no regard to its emission sources;

(b) for each component, the wavelength dependence of the absorption coefficient is proportional to $\lambda^{-\alpha}$, where $\alpha$ is component-dependent;

(c) the Ångström absorption exponent of $\mathrm{BC}\left(\alpha_{\mathrm{BC}}\right)$ is assumed a priori. In this work $\alpha_{\mathrm{BC}}=1$ was set according to expectancies for pure, small BC spheres (e.g., [3]) as often applied in the literature (e.g., [51]). Nevertheless, different choices can be in principle be performed due to the possible effect of BC core and coating sizes on the Ångström absorption exponent (e.g., [52]).

Under the previous assumptions, the total aerosol absorption coefficient can be represented as:

$$
\mathrm{b}_{\mathrm{abs}}(\lambda)=\mathrm{b}_{\mathrm{abs}}{ }^{\mathrm{BC}}(\lambda)+\mathrm{b}_{\mathrm{abs}}{ }^{\mathrm{BrC}}(\lambda)=\mathrm{A} \lambda^{-\alpha_{\mathrm{BC}}}+\mathrm{B} \lambda^{-\alpha_{\mathrm{BrC}}}
$$

Provided that data of $b_{a b s}(\lambda)$ are available for at least $4 \lambda s$, the data can be fitted as a function of $\lambda$ to determine $A, B$, and $\alpha_{\mathrm{BrC}}$ in Equation (1). The result of the fit directly allows calculating component-apportionment of $b_{\mathrm{abs}}(\lambda)$ and provides information on $\alpha_{\mathrm{BrC}}$, which is still rare in the literature for what concerns measurements on not pre-treated samples. Pokhrel et al. [6] performed measurements by multi- $\lambda$ photoacoustic devices on air sampled as-is and after passing through a thermo-denuder, and used different approaches to apportion the $\mathrm{BrC}$ contribution to the total $b_{\mathrm{abs}}$, but no indication of $\alpha_{\mathrm{BrC}}$ was explicitly reported.

Further insights can be obtained exploiting results of the Aethalometer model $[18,19,53]$. The Aethalometer model provides $b_{\mathrm{abs}}(\lambda)$ source apportionment under the following assumptions:

(d) fossil fuels combustion (FF) and wood burning (WB) are the only aerosol sources producing light-absorbing aerosol;

(e) for each source, the absorption coefficient is proportional to $\lambda^{-\alpha}$, where $\alpha$ is source-dependent; 
(f) $\alpha$ for fossil fuel combustion $\left(\alpha_{\mathrm{FF}}\right)$ aerosol is assumed a priori to be the same as $\alpha_{\mathrm{BC}}$-i.e., in this work $\alpha_{\mathrm{FF}}=1$, as is often found in several works from the literature (e.g., [54-56]);

(g) $\alpha$ for wood-burning aerosol $\left(\alpha_{\mathrm{WB}}\right)$ is assumed a priori.

Under the previous assumptions, it holds:

$$
\mathrm{b}_{\mathrm{abs}}(\lambda)=\mathrm{b}_{\mathrm{abs}}{ }^{\mathrm{FF}}(\lambda)+\mathrm{b}_{\mathrm{abs}}{ }^{\mathrm{WB}}(\lambda)=\mathrm{A}^{\prime} \lambda^{-\alpha_{\mathrm{FF}}}+\mathrm{B}^{\prime} \lambda^{-\alpha_{\mathrm{WB}}}
$$

It is noteworthy that in the Aethalometer model $b_{a b s}{ }^{\mathrm{FF}}(\lambda)$ and $b_{\mathrm{abs}}{ }^{\mathrm{WB}}(\lambda)$ are obtained. Unlike the Aethalometer model which derives $\mathrm{A}^{\prime}$ and $\mathrm{B}^{\prime}$ starting from information at two $\lambda \mathrm{s}$ only, with the MWAA model $A^{\prime}$ and $B^{\prime}$ are obtained by fitting $b_{a b s}(\lambda)$ data at all available $\lambda s$ using Equation (2).

To perform source and component apportionment of $b_{a b s}(\lambda)$, the MWAA model combines Equation (1) and Equation (2) under the following assumptions:

(h) $\quad \alpha_{\mathrm{FF}}=\alpha_{\mathrm{BC}}$

(i) $\mathrm{BrC}$ is emitted by wood burning only.

From these assumptions, once $\mathrm{A}, \mathrm{B}, \alpha_{\mathrm{BrC}}, \mathrm{A}^{\prime}$, and $\mathrm{B}^{\prime}$ are obtained by the two fit procedures, $\mathrm{b}_{\mathrm{abs}, \mathrm{FF}}{ }^{\mathrm{BC}}(\lambda), \mathrm{b}_{\mathrm{abs}, \mathrm{WB}}{ }^{\mathrm{BC}}(\lambda)$, and $\mathrm{b}_{\mathrm{abs}}{ }^{\mathrm{BC}}(\lambda)$ can be derived as presented in Equation (3) (details for calculation can be found in Massabò et al. [20] and a sketch of the procedure is present in the supplemental material (1)):

$$
\left\{\begin{array}{l}
\mathrm{b}_{\mathrm{abs}, \mathrm{FF}}{ }^{\mathrm{BC}}(\lambda)=\mathrm{A}^{\prime} \lambda^{-\alpha_{\mathrm{BC}}} \\
\mathrm{b}_{\mathrm{abs}, \mathrm{WB}}{ }^{\mathrm{BC}}(\lambda)=\left(\mathrm{A}-\mathrm{A}^{\prime}\right) \lambda^{-\alpha_{\mathrm{BC}}} \\
\mathrm{b}_{\mathrm{abs}}{ }^{\mathrm{BrC}}(\lambda)=\mathrm{B} \lambda^{-\alpha_{\mathrm{BrC}}}
\end{array}\right.
$$

Among the several parameters needed for running the MWAA model, the choice of the value to be attributed to $\alpha_{W B}$ is the most critical, since it depends, at least, on the kind of wood burnt and on meteorology. In the literature, values between 1.6 and 2 have been reported when performing optical source apportionment of ambient aerosol [18-20,33,57,58]. For this reason, we decided to support our choice exploiting previous information available at each site. In a previous study in Propata, source apportionment was carried out both from ${ }^{14} \mathrm{C}$ and optical measurements. Input $\alpha_{\mathrm{WB}}$ for optical source apportionment was varied and $\alpha_{\mathrm{WB}}=1.8$ gave the best agreement with ${ }^{14} \mathrm{C}$ source apportionment results [20]. Thus, $\alpha_{W B}=1.8$ was used also in this work for the Propata dataset. In the case of Milan, performing the same choice led to an unreasonably high contribution from wood burning compared to previous studies based on ${ }^{14} \mathrm{C}$ measurements [41] or Positive Matrix Factorization on well chemically characterized samples $[40,42]$. So, we finally chose $\alpha_{W B}=2$ in Milan.

\subsubsection{Determination of Equivalent Black Carbon Mass-Absorption Coefficient}

Equivalent black carbon (EBC) in atmosphere is generally calculated from $b_{a b s}$ measurements, assuming that $\mathrm{b}_{\mathrm{abs}}$ is due to black carbon absorption contribution only and using a suitable $\lambda$-dependent mass absorption coefficient $\operatorname{MAC}(\lambda)$.

$$
\mathrm{EBC}=\frac{\mathrm{b}_{\mathrm{abs}}(\lambda)}{\operatorname{MAC}(\lambda)}
$$

The MAC of atmospheric EBC spans a relatively wide range of values in the literature (e.g., [2,54]) and it is recognized to be site- and season-dependent. Among the reasons for this variability, it is worth mentioning the different methodologies used for EBC determination [59] and the neglect of possible components of other $B C$ contributing to $b_{a b s}(\lambda)$ (e.g. mineral dust [60]), together with possible mixing effects (see e.g., [6,61]). As no direct measurement of $B C$ mass is possible [59], the EC measured by thermal-optical transmittance method (par. 2.3) was assumed as a proxy for EBC in this work. 
This allowed providing the EBC MAC (MAC $\mathrm{EBC}_{\text {) }}$ at different $\lambda$ s. Indeed, Equation (4) can be re-written as follows, exploiting $b_{a b s}{ }^{B C}(\lambda)$ obtained by the MWAA model to determine $\operatorname{MAC}(\lambda)$ (Equation (5)):

$$
\operatorname{MAC}_{\mathrm{EBC}}(\lambda) \frac{\mathrm{b}_{\mathrm{abs}}{ }^{\mathrm{BC}}(\lambda)}{\mathrm{EC}}
$$

\subsubsection{EC Source Apportionment}

Assuming EC as a proxy for EBC, as previously mentioned, the $b_{a b s}{ }^{B C}$ source apportionment performed using Equation (3) can be directly exploited to provide EC source apportionment. Total $\mathrm{EC}$ can be apportioned into $\mathrm{EC}$ from fossil fuel combustion $\left(\mathrm{EC}_{\mathrm{FF}}\right)$ and from wood burning $\left(\mathrm{EC}_{\mathrm{WB}}\right)$, as reported in Equation (6):

$$
\mathrm{EC}_{\mathrm{FF}}=\frac{\mathrm{b}_{\mathrm{abs}, \mathrm{FF}}{ }^{\mathrm{BC}}}{\mathrm{b}_{\mathrm{abs}}{ }^{\mathrm{BC}}} \mathrm{EC} \quad \text { and } \quad \mathrm{EC}_{\mathrm{WB}}=\mathrm{EC}-\mathrm{EC}_{\mathrm{FF}}
$$

In principle, any wavelength can be chosen as reference for $b_{a b s}{ }^{B C}$ and $b_{a b s, F F}{ }^{B C}$. Nevertheless, it is expected that lower uncertainty affects optical apportionment at long wavelengths, due to the lower contribution to the total $b_{a b s}$ from BrC. Further detail on the methodology can be found in [20].

\subsubsection{OC Source Apportionment}

OC source apportionment is less straightforward. Indeed, non-absorbing OC by combustion sources and $\mathrm{OC}$ by non-combustion sources $\left(\mathrm{OC}_{\mathrm{NC}}\right)$ can contribute to $\mathrm{OC}$. The methodology used in the MWAA model for OC source apportionment stems from tracer approaches. These methods assume that a component emitted by the source can be clearly apportioned (the tracer) and that another is emitted with constant ratio with the tracer. In this way, the second component can be obtained by the tracer using a suitable emission ratio. The approach is widely used in the literature for OC source apportionment, e.g., based on ${ }^{14} \mathrm{C}$ measurements [41,62]. The approach has already been extended in source apportionment studies based on optical properties, with further assumptions on proportionality between species and optical properties [18-20].

OC source apportionment by the MWAA model assumes that:

(j) $\mathrm{OC}$ from fossil fuel combustion $\left(\mathrm{OC}_{\mathrm{FF}}\right)$ is proportional to $\mathrm{EC}_{\mathrm{FF}}$ and-assuming that the $\mathrm{MAC}$ for $\mathrm{BC}$ has limited variability in the considered dataset- to $_{\mathrm{abs}, \mathrm{FF}}{ }^{\mathrm{BC}}$. It is preferable to perform $\mathrm{OC}$ source apportionment starting from optical measurements to reduce uncertainty propagation;

(k) OC from wood burning combustion $\left(\mathrm{OC}_{\mathrm{WB}}\right.$ ) is proportional to $\mathrm{BrC}$ and-assuming that the MAC for $\mathrm{BrC}$ has limited variability in the considered dataset-to $\mathrm{b}_{\mathrm{abs}}{ }^{\mathrm{BrC}}$; in this case, it is suggested to exploit information on $\mathrm{b}_{\mathrm{abs}} \mathrm{BrC}$ at the shortest available wavelength to maximize the relative contribution of $\mathrm{BrC}$ to the total $\mathrm{b}_{\mathrm{abs}}$.

Summarizing, as $5-\lambda$ measurements are available for both the considered datasets, OC source apportionment will be performed using Equation (7):

$$
\mathrm{OC}=\mathrm{OC}_{\mathrm{FF}}+\mathrm{OC}_{\mathrm{WB}}+\mathrm{OC}_{\mathrm{NC}}=\mathrm{k}_{1} \cdot \mathrm{b}_{\mathrm{abs}}{ }^{\mathrm{BC}}(850 \mathrm{~nm})+\mathrm{k}_{2} \cdot \mathrm{b}_{\mathrm{abs}}{ }^{\mathrm{BrC}}(375 \mathrm{~nm})+\mathrm{OC}_{\mathrm{NC}}
$$

Massabò et al. [20] proposed to determine $\mathrm{k}_{1}$ on samples where little wood burning impact was expected, so that Equation (7) reduces to $O C=k_{1} \cdot b_{a b s}{ }^{B C}(850 \mathrm{~nm})+O C_{N C}$. Nevertheless, such approach is hardly applicable when only winter samples are available, especially at sites where high contribution due to wood burning for domestic heating is expected. So, in this work we propose to obtain $k_{1}$ and $k_{2}$ by multiple linear regression of $\mathrm{OC}$ vs. $\mathrm{b}_{\mathrm{abs}}{ }^{\mathrm{BC}}(850 \mathrm{~nm})$ and $\mathrm{b}_{\mathrm{abs}}{ }^{\mathrm{BrC}}(375 \mathrm{~nm})$, under the assumption that $\mathrm{OC}_{\mathrm{NC}}$ can be assumed nearly constant or provides a minor contribution to total OC.

The main limitation of the method is related to possible difficulties in apportioning secondary OC. Nevertheless, $\mathrm{k}_{1}$ and $\mathrm{k}_{2}$ are derived by multiple linear regression of real-world measurements. 
Real-world profiles have already been proven to have the potential to account for rapidly formed secondary compounds, thus limiting the problem of secondary OC apportionment only to secondary $\mathrm{OC}$ formed with great time-delay from precursor emissions (which can provide contribution to $\left.\mathrm{OC}_{\mathrm{NC}}\right)[44,63]$.

\section{Results}

\subsection{Results from the Propata Dataset}

The 5- $\lambda$ temporal trend of $b_{a b s}$ measured in Propata using the MWAA instrument is shown in Figure 2, together with the apparent Ångström absorption coefficient $\left(\alpha_{\text {exp }}\right.$, determined by fitting each set of $5-\lambda$ data by a $\lambda^{-\alpha \exp }$ function). It should be noted that $\alpha_{\exp }$ was in the range $1.31-1.85$, providing a first indication of important contributions by sources other than fossils during the whole period.

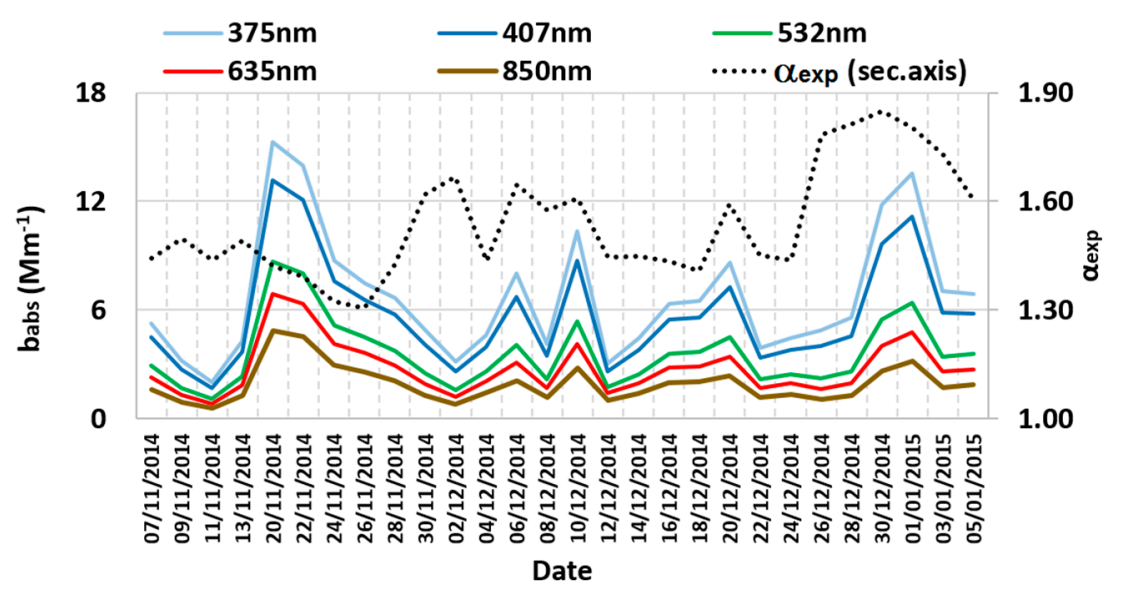

Figure 2. $5-\lambda$ aerosol absorption coefficient $\left(b_{a b s}\right)$ and the Ångström absorption coefficient $\left(\alpha_{\exp }\right)$ determined on the Propata dataset. Date referring to the beginning of the sampling is reported on the $\mathrm{x}$-axis.

The MWAA model was run on the Propata dataset, as explained in par. 2.4. In Figure 3, results obtained for $\alpha_{\mathrm{BrC}}$ and fit error are represented. It is noteworthy that in $79 \%$ cases, the fit error was lower than $3 \%$. In these cases, very close $\alpha_{\mathrm{BrC}}$ values were found in different samples: $\alpha_{\mathrm{BrC}}=3.79 \pm 0.10$ (i.e., $2.5 \%$ standard deviation) with a minimum-maximum range of 3.58-3.99.

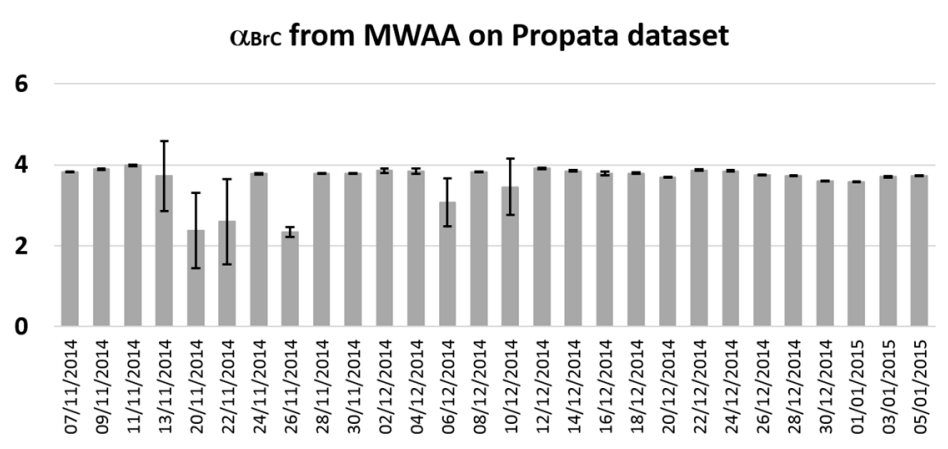

Figure 3. BrC Ångström Absorption exponent $\left(\alpha_{\mathrm{BrC})}\right.$ and associated fit uncertainty for the Propata dataset. Date referring to the beginning of the sampling is reported on the x-axis.

Assuming wood burning as the main source of $\mathrm{BrC}$, we analyzed the correlation between $\mathrm{b}_{\mathrm{abs}}{ }^{\mathrm{BrC}}(\lambda)$ and levoglucosan (tracer for wood burning). It was noticed that the correlation decreased at increasing wavelengths (see as an example the scatterplots of $b_{a b s}{ }^{B r C}(\lambda)$ at $375 \mathrm{~nm}$ and $850 \mathrm{~nm}$ vs. levoglucosan 
concentration shown in Figure 4a). Furthermore, the most scattered points were those showing high uncertainties for $\alpha_{\mathrm{BrC}}$.

Two hypotheses were performed concerning these points:

(a) The two-component model was not applicable. This can occur, e.g., in case of Saharan dust events when a non-negligible absorption contribution from dust can be, in principle, observed. Furthermore, it should be recalled that $\mathrm{BrC}$ refers to a complex mixture of organic compounds still poorly characterized. It cannot be excluded that $\mathrm{BrC}$ of various origins (e.g., wood burning vs. photochemical contribution) can have different features.

(b) Numerical tests showed that quality of the MWAA model fit is quite sensitive to input data, even for input data variations within uncertainties. Random combination of data uncertainties can lead to configurations in the $5-\lambda b_{a b s}$ measurements, badly affecting the fit: e.g., numerical tests performed by shifting (within uncertainties) towards higher values $b_{a b s}$ at short- $\lambda$ and towards lower values $b_{\mathrm{abs}}$ at long- $\lambda$ showed important variations in $\alpha_{\mathrm{BrC}}$ results and an increase in the associated uncertainties.

Trying to understand which of these hypotheses affected the points with high uncertainties on $\alpha_{\mathrm{BrC}}$, the MWAA model was re-run in a different way: fit of Equation (1) was performed by fixing $\alpha_{\mathrm{BrC}}=3.79$. This value has been calculated by averaging the $\alpha_{\mathrm{BrC}}$ values, considering only samples where the relative uncertainty was lower than $3 \%$. This approach will henceforth be named "MWAA model with fixed $\alpha_{\mathrm{BrC}}$ ". The results obtained in this case for $\mathrm{b}_{\mathrm{abs}}{ }^{\mathrm{BrC}}(\lambda)$ at $375 \mathrm{~nm}$ and $850 \mathrm{~nm}$ vs. levoglucosan concentration are reported in Figure $4 \mathrm{~b}$. It is noteworthy that correlation at $850 \mathrm{~nm}$ strongly improved $\left(R^{2}=0.96\right)$. This suggested that numerical instability was responsible for the few samples with $\alpha_{\mathrm{BrC}}$ affected by high uncertainties in Figure 3. Indeed, if a third absorbing component independent of wood burning was present in the dataset, no improving correlation with levoglucosan could be expected, even when imposing a $\alpha_{\mathrm{BrC}}$ characteristic for wood burning at the sampling site.
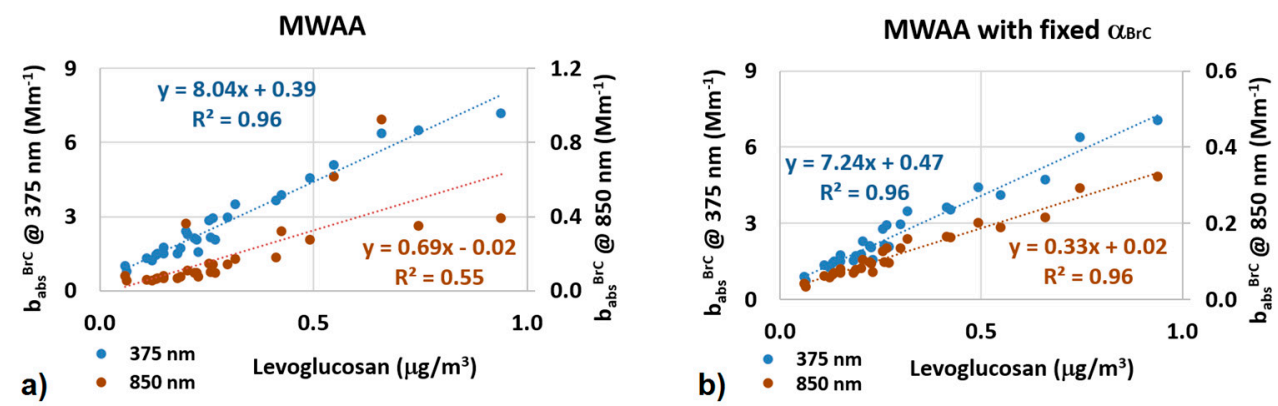

Figure 4. Scatterplot of $b_{a b s}{ }^{B r C}(375 \mathrm{~nm})$ and $b_{a b s}{ }^{B r C}(850 \mathrm{~nm})$ vs. levoglucosan concentration obtained in Propata running: (a) the original MWAA model, (b) MWAA model with fixed $\alpha_{\mathrm{BrC}}$.

Total carbon (TC) absolute concentration in the Propata dataset was $1.7 \pm 0.7 \mu \mathrm{g} / \mathrm{m}^{3}$ (average \pm standard deviation). OC represented, on average, $82 \%$ of TC, the remaining $18 \%$ being EC. Levoglucosan average concentration in Propata was $0.3 \pm 0.2 \mu \mathrm{g} / \mathrm{m}^{3}$.

EC source apportionment was performed as explained in par. 2.4.3, starting from $b_{a b s}$ source apportionment obtained by the MWAA model with fixed $\alpha_{\mathrm{BrC}}$. The relative contribution of $\mathrm{EC}_{\mathrm{FF}}$ (Equation (6)) to EC in Propata was 37\% $\pm 22 \%$ (average \pm standard deviation). Very good correlation was found between $E C_{W B}$ and levoglucosan $\left(R^{2}=0.90\right.$, see Figure 5). The average levoglucosan $/ E C_{W B}$ ratio in these samples was $1.6 \pm 0.4$. It is within the range obtained combining information on levoglucosan/OC and EC/OC ratios for wood burning emissions reported in [62] and the literature therein $(0.9 \pm 0.6)$. 


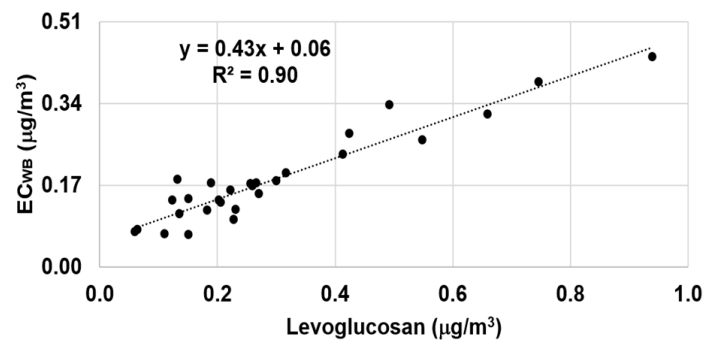

Figure 5. Scatterplot of EC from wood burning $\left(\mathrm{EC}_{\mathrm{WB}}\right)$ vs. levoglucosan on Propata dataset.

Multiple linear regression was carried out for OC source apportionment as explained in Section 2.4.4. Regression parameters were $\mathrm{k}_{1}=0.24 \pm 0.06, \mathrm{k}_{2}=0.35 \pm 0.02$, and $\mathrm{OC}_{\mathrm{NC}}=0.30 \pm 0.08$, in which uncertainties represent the standard error of the regression. Scatterplot of reconstructed vs. measured OC concentration resulted into $\mathrm{OC}_{\text {rec }}=0.98 \cdot \mathrm{OC}_{\text {meas, }}$, with $\mathrm{R}^{2}=0.89$. OC in Propata was dominated by $\mathrm{OC}_{\mathrm{WB}}(63 \% \pm 16 \%)$ and the contribution from fossil fuel combustion was much lower $(13 \% \pm 10 \%)$. Non-negligible contribution resulting from $\mathrm{OC}_{\mathrm{NC}}$ was present $(25 \% \pm 9 \%)$, and it is expected to be related to secondary and/or natural contributions. $\mathrm{OC}_{\mathrm{FF}} / \mathrm{EC}_{\mathrm{FF}}$ ratio was $1.4 \pm 0.3$, which is in agreement with, e.g., real-world profiles for the traffic source obtained by PMF in Milan [40]. $\mathrm{OC}_{\mathrm{WB}} / \mathrm{EC}_{\mathrm{WB}}$ ratio in Propata was $5.0 \pm 1.2$. This ratio is within the range reported for primary wood burning emissions $\left(\mathrm{EC}_{\mathrm{WB}} / \mathrm{OC}_{\mathrm{WB}}=0.16 \pm 0.05\right.$ was reported in [62] and therein-cited literature, i.e., $\mathrm{OC}_{\mathrm{WB}} / \mathrm{EC}_{\mathrm{WB}}=6.3 \pm 2.0$ ). Nevertheless, it should be noticed that literature ratios were obtained from OC and EC measurements carried out with different thermal protocols, whose influence on the measurements will be better discussed in par. 4 .

\subsection{Results from the Milan Dataset}

Multi- $\lambda b_{a b s}$ measurements on the Milan dataset were performed both using PP_UniMI and MWAA. As shown in par. 2.2, measurements agreed very well between the instruments. In this paragraph, data obtained by the MWAA instrument will be presented throughout the text as they were performed at $5-\lambda \mathrm{s}$ (compared to $4-\lambda$ measurements performed by PP_UniMI). This improves the quality of the fits to be performed, as presented in par. 2.4.1 due to a higher number of points.

Figure 6 represents the $5-\lambda$ temporal trend of $b_{a b s}$ and $\alpha_{\exp }$ for the Milan dataset. In this dataset $1.19 \leq \alpha_{\exp } \leq 1.69$ : values were lower than in Propata, providing a first indication of a higher relative contribution from fossil fuel combustion.

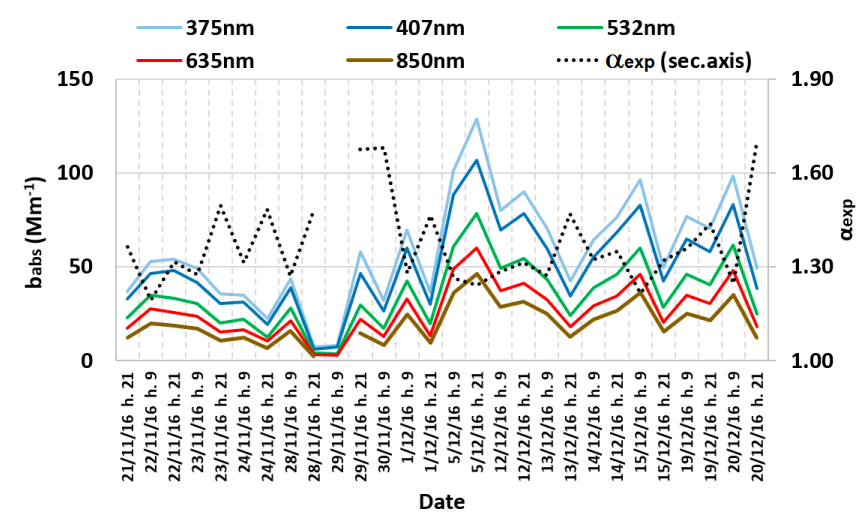

Figure 6. $5-\lambda b_{a b s}$ and $\alpha_{\exp }$ determined on the Milan dataset. Date and time referring to the beginning of the sampling are reported on the $x$-axis.

As already shown for Propata, Figure 7 represents $\alpha_{\mathrm{BrC}}$ and uncertainties obtained by the MWAA model. For the Milan dataset, $\alpha_{\mathrm{BrC}}$ uncertainty provided by the fit is lower than $3 \%$ only in $41 \%$ of the 
samples (in 75\% cases it was lower than 10\%). Nevertheless, as already found in Propata, stable values for $\alpha_{\mathrm{BrC}}$ were obtained when uncertainty was $<3 \%$ : $\alpha_{\mathrm{BrC}}=3.81 \pm 0.11$ (i.e., $3 \%$ relative standard deviation) with a minimum-maximum range of 3.72-4.14. These values of $\alpha_{\mathrm{BrC}}$ are fully comparable to those obtained in Propata within variability (see Table 1).

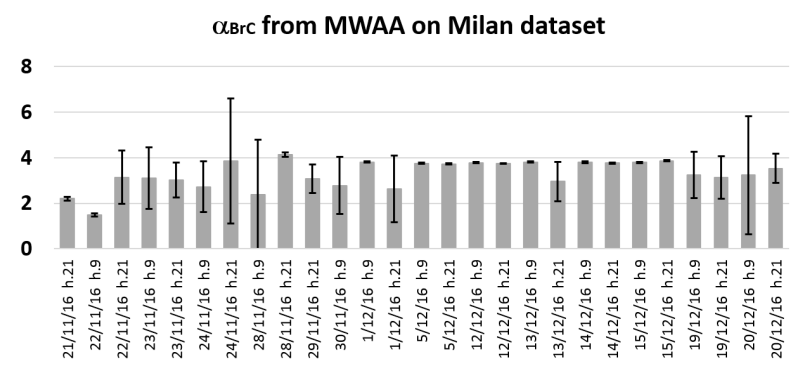

Figure 7. $\alpha_{\mathrm{BrC}}$ and associated fit uncertainty for the Milan dataset. Date and time referring to the beginning of the sampling are reported on the $\mathrm{x}$-axis.

Table 1. Summary of values and standard error for $\alpha_{\mathrm{BrC}}$ in samples with relative uncertainties $<3 \%, \mathrm{k}_{1}$, and $\mathrm{k}_{2}$.

\begin{tabular}{|c|c|c|c|}
\hline & $\alpha_{\mathrm{BrC}}$ & $\begin{array}{c}\mathbf{k}_{1} \\
\mu \mathrm{g} /\left(\mathrm{m}^{3} \mathrm{Mm}^{-1}\right)\end{array}$ & $\begin{array}{c}\mathbf{k}_{2} \\
\mu \mathrm{g} /\left(\mathrm{m}^{3} \mathrm{Mm}^{-1}\right)\end{array}$ \\
\hline Propata & $3.79 \pm 0.10$ & $0.24 \pm 0.06$ & $0.35 \pm 0.02$ \\
\hline Milan & $3.81 \pm 0.11$ & $0.33 \pm 0.05$ & $0.34 \pm 0.07$ \\
\hline
\end{tabular}

Table 2. Summary of values and variability for levoglucosan $/ \mathrm{EC}_{\mathrm{WB}}$ ratio, $\mathrm{OC}_{\mathrm{NC}}, \mathrm{OC}_{\mathrm{FF}} / \mathrm{EC}_{\mathrm{FF}}$, $\mathrm{OC}_{\mathrm{WB}} / \mathrm{EC}_{\mathrm{WB}}, \mathrm{MAC}(\mathrm{BC})$, and applied thermal protocol in Propata and Milan.

\begin{tabular}{ccccccc}
\hline & levo/EC & $\begin{array}{c}\mathrm{OC}_{\mathrm{WB}} \\
\left(\mu \mathrm{g} / \mathbf{m}^{3}\right)\end{array}$ & $\mathrm{OC}_{\mathrm{FF}} / \mathrm{EC}_{\mathrm{FF}}$ & $\mathrm{OC}_{\mathrm{WB}} / \mathrm{EC}_{\mathrm{WB}}$ & $\begin{array}{c}\mathrm{MAC} \\
\left(\mathbf{m}^{2} / \mathbf{g}\right)\end{array}$ & TOT protocol \\
\hline $\begin{array}{c}\text { Propata } \\
\text { Milan }\end{array}$ & $1.6 \pm 0.4$ & $0.30 \pm 0.08$ & $1.4 \pm 0.3$ & $5.0 \pm 1.2$ & $6.3 \pm 1.1$ & EUSAAR_2 \\
\hline
\end{tabular}

In Figure 8a, the scatterplot of $\mathrm{b}_{\mathrm{abs}}{ }^{\mathrm{BrC}}(\lambda)$ at $375 \mathrm{~nm}$ and $850 \mathrm{~nm}$ vs. levoglucosan concentration is reported. It is noteworthy that data were more scattered than for Propata dataset (Figure $4 \mathrm{a}$ ): $\mathrm{R}^{2}=0.71$ was found considering $b_{a b s}(375 \mathrm{~nm})$, whereas no trend line was inserted considering $b_{a b s}(850 \mathrm{~nm})$ as no correlation is found. As already performed for Propata, the MWAA model with fixed $\alpha_{\mathrm{BrC}}$ was re-run also for the Milan dataset. In this test, $\alpha_{\mathrm{BrC}}=3.81$ was chosen, as it is the value obtained for the Milan dataset in the case of good fit of the original data. It can be noticed (Figure $8 \mathrm{~b}$ ) that also in this case the correlation between $b_{a b s}{ }^{B r C}$ and levoglucosan improves in all cases $\left(R^{2}=0.93\right)$.
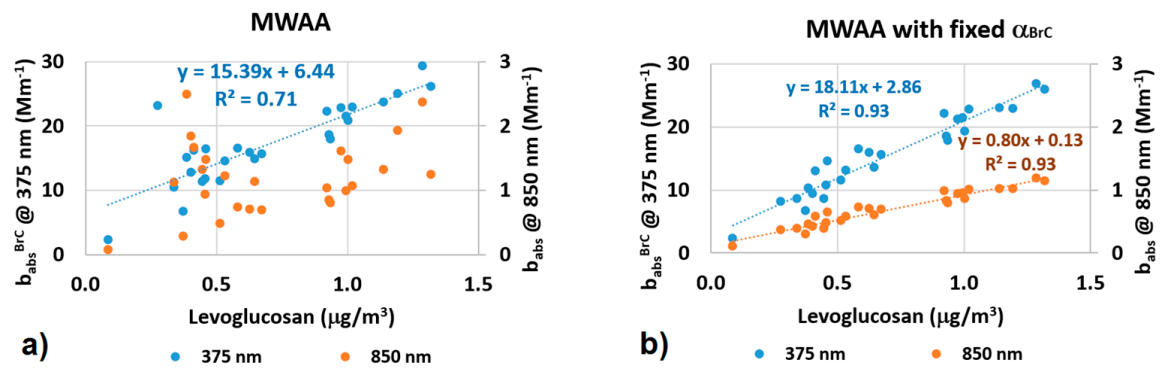

Figure 8. Scatterplot of $\mathrm{b}_{\mathrm{abs}}{ }^{\mathrm{BrC}}(375 \mathrm{~nm})$ and $\mathrm{b}_{\mathrm{abs}}{ }^{\mathrm{BrC}}(850 \mathrm{~nm})$ vs. levoglucosan concentration in Milan obtained running: (a) the original MWAA model, (b) MWAA model with fixed $\alpha_{\mathrm{BrC}}$. 
TC average concentration in Milan was $13 \pm 5 \mu \mathrm{g} / \mathrm{m}^{3}$. On average, $84 \%$ of TC was OC, with the remainder being EC. Levoglucosan average concentration in Milan was $0.7 \pm 0.3 \mu \mathrm{g} / \mathrm{m}^{3}$.

Also for the Milan dataset, data obtained by running the MWAA model with fixed $\alpha_{\mathrm{BrC}}$ were used for EC and OC apportionment. From optical apportionment (Equation (6)), EC resulted mainly of fossil origin in most cases (range 62-87\%, except three cases in the range $42-44 \%$ ), consistent with ${ }^{14} \mathrm{C}$ studies in the Milan area [40] and in other cities in Europe during wintertime [62,64]. As already found between $b_{a b s}{ }^{B r C}$ and levoglucosan, very good correlation was found also between $b_{a b s, W B}{ }^{B C}$ and levoglucosan $\left(R^{2}=0.92\right)$. Nevertheless, only discrete correlation was found between $E C_{W B}$ and levoglucosan $\left(R^{2}=0.56\right)$. It should be evidenced that the initial correlation between $b_{a b s}(850 \mathrm{~nm})$ and EC is lower than in Propata $\left(R^{2}=0.83\right.$ in Milan vs. $R^{2}=0.94$ in Propata), and this can affect the apportionment of absolute EC concentrations. Furthermore, it should be noticed that in four samples ABS values higher than 0.90 were found. In these cases, shadowing effects (e.g., [36]) can occur leading to an underestimation of the measured $b_{a b s}$, thus increasing measurement uncertainty and possibly impacting also the source apportionment model. By removing these points, the correlation rises to $\mathrm{R}^{2}=0.70$ (Figure 9). The average levoglucosan/EC $\mathrm{WB}_{\mathrm{B}}$ ratio in these samples was $1.3 \pm 0.5$, which is fully comparable with the value obtained combining information on levoglucosan/OC and EC/OC ratios for wood-burning emissions reported in [62] and therein-cited literature $(0.9 \pm 0.6)$. Furthermore, the value is fully comparable to the one obtained in Propata within variabilities (see Table 2).

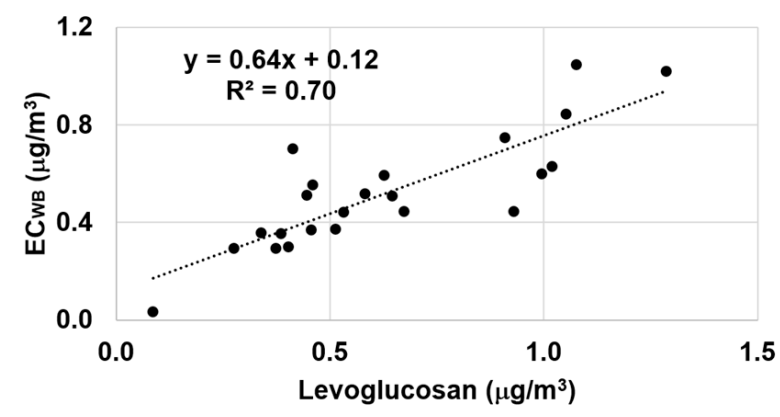

Figure 9. $\mathrm{EC}_{\mathrm{WB}}$ vs. levoglucosan scatterplot for samples with $\mathrm{ABS}(375 \mathrm{~nm})<0.9$.

Multiple linear regression for OC source apportionment (Section 2.4.4) on Milan dataset resulted in $\mathrm{k}_{1}=0.33 \pm 0.05, \mathrm{k}_{2}=0.34 \pm 0.07$, and $\mathrm{OC}_{\mathrm{NC}}=1.1 \pm 1.0$, where uncertainties are the standard error of the regression. It is noteworthy that $\mathrm{OC}_{\mathrm{NC}}$ is comparable to zero within 2 standard errors. Reconstructed vs. measured OC concentration resulted into $\mathrm{OC}_{\text {rec }}=0.98 \cdot \mathrm{OC}_{\text {meas, }}$, with $\mathrm{R}^{2}=0.82$. Moreover, about $\pm 20 \%$ difference between measured and reconstructed concentration was registered, except in two samples. These samples were the same providing the two lowest values for $\alpha_{\mathrm{BrC}}$ (Figure 7). This suggests that these samples are impacted by different sources/processes modifying the optical characteristics compared to the others (e.g., [52]); for this reason, they will be excluded by the following statistics. As far as $\mathrm{OC}_{\mathrm{FF}}, \mathrm{OC}_{\mathrm{WB}}$, and $\mathrm{OC}_{\mathrm{NC}}$ are concerned, they contributed $40 \% \pm 14 \%$, $48 \% \pm 14 \%$, and $12 \% \pm 4 \%$ to the $\mathrm{OC}$, respectively (average \pm standard deviation). $\mathrm{OC}_{\mathrm{FF}} / \mathrm{EC}_{\mathrm{FF}}$ average ratio was $3.0 \pm 0.7$. This value was higher than the ratio expected for primary emission (e.g., [65] and therein-cited literature), but it was compatible to the average $\mathrm{OC}_{\mathrm{FF}} / \mathrm{EC}_{\mathrm{FF}}$ previously found in Milan from ${ }^{14} \mathrm{C}$ measurements $(2.3 \pm 0.8)$ within variability [41]. $\mathrm{OC}_{\mathrm{WB}} / \mathrm{EC}_{\mathrm{WB}}$ average ratio was $10 \pm 3$. Also, in this case, this ratio is higher than what reported for primary wood burning emissions $\left(\mathrm{EC}_{\mathrm{WB}} / \mathrm{OC}_{\mathrm{WB}}=0.16 \pm 0.05\right.$ was reported in [62], i.e., $\left.\mathrm{OC}_{\mathrm{WB}} / \mathrm{EC}_{\mathrm{WB}}=6.3 \pm 2.0\right)$. Nevertheless, literature works suggest that secondary contribution from wood burning comparable to the primary one can be expected $[66,67]$. Thus, the approach seems able to associate at least part of the secondary compounds rapidly formed in atmosphere to specific sources. This ability of receptor models has already been evidenced in other source apportionment studies based on chemical aerosol properties carried out in the area $[44,63]$. 


\section{Discussion}

By comparing the results obtained in the two datasets, two features appeared:

(a) The MWAA model provided more robust measurements of $\alpha_{\mathrm{BrC}}$ on single samples in the Propata dataset (in $79 \%$ vs. $41 \%$ of the cases the fit uncertainty associated with $\alpha_{\mathrm{BrC}}$ is lower than $3 \%$ ).

(b) More samples with high uncertainty associated to $\alpha_{\mathrm{BrC}}$ lead to a lower correlation between $\mathrm{b}_{\mathrm{abs}}{ }^{\mathrm{BrC}}$ and levoglucosan concentration in Milan.

In principle, the latter observation can be related to site-specific characteristics (e.g. source mixture or particle aging), to numeric instability, or both. The results of the test performed by fixing $\alpha_{\mathrm{BrC}}$ at each site to the average value for $\alpha_{\mathrm{BrC}}$ low-uncertainty samples showed that correlation between $b_{\mathrm{abs}} \mathrm{BrC}$ and levoglucosan improved. This provided an indication that wood burning (traced by levoglucosan) dominated $\mathrm{BrC}$ concentration at both sites. Indeed, if contributions from other sources emitting important absorbers or $\mathrm{BrC}$ species with strongly different optical properties were present in the samples, a weaker correlation with a marker from a specific source would have been found.

Nevertheless, it can be noticed that $\mathrm{b}_{\mathrm{abs}}{ }^{\mathrm{BrC}} \mathrm{vs}$. levoglucosan correlation is slightly worse in Milan $\left(R^{2}=0.93\right)$ than in Propata $\left(R^{2}=0.96\right)$. Possible reasons could be the more complex mixture of sources present in Milan and the aging processes [40,42,44], which can affect aerosol composition, particle mixing, and size distribution. Small variations in $\mathrm{BrC}$ properties related to these factors could have influenced the MWAA model results, leading to a higher percent of cases in which $\alpha_{\mathrm{BrC}}$ was affected by high uncertainties.

Absolute TC average concentrations at the two sites were 7.7 times higher in Milan than in Propata. This is consistent with the peculiarities of the sites: Milan is placed in the Po Valley, which is one of the main hot-spot pollution areas, and it is often affected by strong stability conditions during wintertime [68,69]; Propata is a small village in the Appennines; very few local sources are present in Propata and it is only occasionally impacted by transports from the Po Valley. The high wood-burning contributions of EC and OC in Propata are easily explained by the wide use of wood burning for domestic heating at the site. Even if the relative contribution of OC and EC to TC seems to be comparable at the two sites, it should be recalled (par. 2.3) that carbonaceous fractions were measured by the EUSAAR_2 protocol in Propata and by a NIOSH-like protocol (He_870) in Milan. In a previous study [50], it was shown that the ratio of EC measured with the two protocols was $\mathrm{EC}_{\mathrm{EUSAAR} \_2} / \mathrm{EC}_{\mathrm{He} \_870}=1.49$ for winter samples collected in Milan. Thus, relative EC contribution to TC reported to the same thermal protocol is about 1.5 times higher in Milan than in Propata. The use of different thermal protocols and their effect on EC quantification impacted also on apparent MAC (Equation (5)) measured at the sites: the MAC was $6.3 \pm 1.1 \mathrm{~m}^{2} / \mathrm{g}$ and $9.1 \pm 1.9 \mathrm{~m}^{2} / \mathrm{g}$ at $850 \mathrm{~nm}$ in Propata and Milan, respectively. If the influence of the thermal protocol on EC quantification is considered, the MAC values determined at the two sites are fully comparable within variabilities and they are in the range of results recently reported in the literature in the European boundary layer [70].

It is very interesting to note that both the constant $k_{1}$ relating $b_{a b s}{ }^{B C}(850 \mathrm{~nm})$ to $\mathrm{OC}_{\mathrm{FF}}$ and $\mathrm{k}_{2}$ relating $b_{a b s}{ }^{\mathrm{BrC}}(375 \mathrm{~nm})$ to $\mathrm{OC}_{\mathrm{WB}}$ were compatible within uncertainties between the sites (see Table 1 ). Nevertheless, OC/EC ratios were much higher in Milan than in Propata for both fossil fuel combustion and wood burning contributions, especially considering the differences in EC and OC quantification related to the thermal protocol (see Table 2). This can be related to the peculiarity of the Milan site: stagnation conditions may foster aging processes, increasing the OC/EC ratio [65]. As the ability of receptor models to relate rapidly-formed secondary compounds to the primary emitted species has been proven in the literature [44,63], rapidly-formed secondary compounds in Milan can be associated to primary emissions by the model. This seems to occur to a lesser extent in Propata, where the relative contribution from $\mathrm{OC}_{\mathrm{NC}}$ to $\mathrm{OC}$ was more than twice the one in Milan. This can be related both to less stable meteorological conditions and to a cleaner and less reactive atmosphere. 


\section{Conclusions}

The MWAA model was used for optical source and component apportionment of the total aerosol absorption coefficients measured at different wavelengths during wintertime at two sites with different characteristics (an urban site in the Po Valley, Milan and a rural site in the Appennines, Propata), as well as to gain information on $\alpha_{\mathrm{BrC}}$ value.

The results showed that $\alpha_{\mathrm{BrC}}$ determination was affected by lower uncertainties in Propata than in Milan, where a more complex mixture of sources can affect model performances. Nevertheless, it was shown that the application of the MWAA model by fixing $\alpha_{\mathrm{BrC}}$ led to an improvement in component apportionment. The fixed $\alpha_{\mathrm{BrC}}$ corresponded to the average value obtained for the samples where $\alpha_{\mathrm{BrC}}$ was determined with low uncertainties. A very good correlation $\left(R^{2}>0.93\right)$ was found at both sites between $\mathrm{b}_{\mathrm{abs}}{ }^{\mathrm{BrC}}(375 \mathrm{~nm})$ and levoglucosan, identifying wood burning as the main contributor to $\mathrm{BrC}$ in the investigated areas.

The simultaneous component apportionment and EC measurements allowed us to determine the $\mathrm{BC}$ mass absorption coefficient. The latter was comparable within variability at the two sites when the role of different thermal protocols on EC quantification was considered.

OC and EC source apportionment showed that wood burning was the dominating contributor to both carbon fractions in Propata, whereas a more complex situation was detected in Milan. A relationship between samples resulting in very low $\alpha_{\mathrm{BrC}}$ value in Milan and bad OC apportionment was also apparent; in these samples, the impact of other sources can be assumed, and the two-sources scheme seems not to be applicable. In other cases, good performances were detected.

As a perspective, the application of the MWAA model to sites with different characteristics will promote the gathering of reliable information on the $\lambda$-dependence characteristics of $\mathrm{BrC}$ absorption properties at different sites, as well as gaining information on $\mathrm{MAC}_{\mathrm{EBC}}$, by exploiting the ability of the model to separate different component contributions to the total $b_{\mathrm{abs}}$, together information on EC mass obtainable by other analytical techniques.

Supplementary Materials: The following are available online at www.mdpi.com/2073-4433/8/11/218/s1.

Acknowledgments: This work has been partially financed by the National Institute of Nuclear Physics (INFN) in the frame of the DEPOTMASS and TRACCIA experiments. The authors acknowledge Vincenzo Ariola and Franco Parodi (INFN-Genova) for technical support in the MWAA instrument development.

Author Contributions: Vera Bernardoni and Dario Massabò conceived and designed the experiments; Rosaria Erika Pileci and Dario Massabò performed the sampling campaigns and laboratory measurements; Dario Massabò and Lorenzo Caponi run the MWAA model; Vera Bernardoni and Dario Massabò performed data analysis and reduction and wrote the manuscript. All co-authors commented on the results and on the manuscript content.

Conflicts of Interest: The authors declare no conflict of interest.

\section{References}

1. IPCC. Climate Change 2013: The Physical Science Basis. Contribution of Working Group I to the Fifth Assessment Report of the Intergovernmental Panel on Climate Change; Stocker, T.F., Qin, D., Plattner, G.-K., Tignor, M., Allen, S.K., Boschung, J., Nauels, A., Xia, Y., Bex, V., Midgley, P.M., Eds.; Cambridge University Press: Cambridge, UK, 2013; ISBN 78-1-107-05799-1.

2. Bond, T.C.; Doherty, S.J.; Fahey, D.W.; Forster, P.M.; Berntsen, T.; DeAngelo, B.J.; Flanner, M.G.; Ghan, S.; Kärcher, B.; Koch, D.; et al. Bounding the role of black carbon in the climate system: A scientific assessment. J. Geophys. Res. Atmos. 2013, 118, 5380-5552. [CrossRef]

3. Moosmüller, H.; Chakrabarty, R.K.; Arnott, W.P. Aerosol light absorption and its measurement: A review. J. Quant. Spectrosc. Radiat. Transf. 2009, 110, 844-878. [CrossRef]

4. Andreae, M.O.; Gelencsér, A. Black carbon or brown carbon? The nature of light-absorbing carbonaceous aerosols. Atmos. Chem. Phys. 2006, 6, 3131-3148. [CrossRef]

5. Lack, D.A.; Cappa, C.D. Impact of brown and clear carbon on light absorption enhancement, single scatter albedo and absorption wavelength dependence of black carbon. Atmos. Chem. Phys. 2010, 4207-4220. [CrossRef] 
6. Pokhrel, R.P.; Beamesderfer, E.R.; Wagner, N.L.; Langridge, J.M.; Lack, D.A.; Jayarathne, T.; Stone, E.A.; Stockwell, C.E.; Yokelson, R.J.; Murphy, S.M. Relative importance of black carbon, brown carbon, and absorption enhancement from clear coatings in biomass burning emissions. Atmos. Chem. Phys. 2017, 17, 5063-5078. [CrossRef]

7. Knox, A.; Evans, G.J.; Brook, J.R.; Yao, X.; Jeong, C.-H.; Godri, K.J.; Sabaliauskas, K.; Slowik, J.G. Mass Absorption Cross-Section of Ambient Black Carbon Aerosol in Relation to Chemical Age. Aerosol Sci. Technol. 2009, 43, 522-532. [CrossRef]

8. Cappa, C.D.; Onasch, T.B.; Massoli, P.; Worsnop, D.R.; Bates, T.S.; Cross, E.S.; Davidovits, P.; Hakala, J.; Hayden, K.L.; Jobson, B.T.; et al. Radiative Absorption Enhancements Due to the Mixing State of Atmospheric Black Carbon. Science 2012, 337, 1078-1081. [CrossRef] [PubMed]

9. Liu, S.; Aiken, A.C.; Gorkowski, K.; Dubey, M.K.; Cappa, C.D.; Williams, L.R.; Herndon, S.C.; Massoli, P.; Fortner, E.C.; Chhabra, P.S.; et al. Enhanced light absorption by mixed source black and brown carbon particles in UK winter. Nat. Commun. 2015, 6, 8435. [CrossRef] [PubMed]

10. Wei, Y.; Ma, L.; Cao, T.; Zhang, Q.; Wu, J.; Buseck, P.R.; Thompson, J.E. Light Scattering and Extinction Measurements Combined with Laser-Induced Incandescence for the Real-Time Determination of Soot Mass Absorption Cross Section. Anal. Chem. 2013, 85, 9181-9188. [CrossRef] [PubMed]

11. Saleh, R.; Robinson, E.S.; Tkacik, D.S.; Ahern, A.T.; Liu, S.; Aiken, A.C.; Sullivan, R.C.; Presto, A.A.; Dubey, M.K.; Yokelson, R.J.; et al. Brownness of organics in aerosols from biomass burning linked to their black carbon content. Nat. Geosci. 2014, 7, 647-650. [CrossRef]

12. Di Lorenzo, R.A.; Washenfelder, R.A.; Attwood, A.R.; Guo, H.; Xu, L.; Ng, N.L.; Weber, R.J.; Baumann, K.; Edgerton, E.; Young, C.J. Molecular-Size-Separated Brown Carbon Absorption for Biomass-Burning Aerosol at Multiple Field Sites. Environ. Sci. Technol. 2017, 51, 3128-3137. [CrossRef] [PubMed]

13. Lu, Z.; Streets, D.G.; Winijkul, E.; Yan, F.; Chen, Y.; Bond, T.C.; Feng, Y.; Dubey, M.K.; Liu, S.; Pinto, J.P.; et al. Light Absorption Properties and Radiative Effects of Primary Organic Aerosol Emissions. Environ. Sci. Technol. 2015, 49, 4868-4877. [CrossRef] [PubMed]

14. Lack, D.A.; Bahreini, R.; Langridge, J.M.; Gilman, J.B.; Middlebrook, A.M. Brown carbon absorption linked to organic mass tracers in biomass burning particles. Atmos. Chem. Phys. 2013, 13, 2415-2422. [CrossRef]

15. Washenfelder, R.A.; Attwood, A.R.; Brock, C.A.; Guo, H.; Xu, L.; Weber, R.J.; Ng, N.L.; Allen, H.M.; Ayres, B.R.; Baumann, K.; et al. Biomass burning dominates brown carbon absorption in the rural southeastern United States. Geophys. Res. Lett. 2015, 42, 653-664. [CrossRef]

16. Xie, M.; Hays, M.D.; Holder, A.L. Light-absorbing organic carbon from prescribed and laboratory biomass burning and gasoline vehicle emissions. Sci. Rep. 2017, 7, 7318. [CrossRef] [PubMed]

17. Yan, C.; Zheng, M.; Bosch, C.; Andersson, A.; Desyaterik, D.; Sullivan, A.P.; Collett, J.L.; Zhao, B.; Wang, S.; $\mathrm{He}, \mathrm{K}$; i et al. Important fossil source contribution to brown carbon in Beijing during winter. Sci. Rep. 2017, 7, 43182. [CrossRef] [PubMed]

18. Sandradewi, J.; Prévôt, A.S.; Szidat, S.; Perron, N.; Alfarra, M.R.; Lanz, V.A.; Weingartner, E.; Baltensperger, U. Using aerosol light absorption measurements for the quantitative determination of wood burning and traffic emission contributions to particulate matter. Environ. Sci. Technol. 2008, 42, 3316-3323. [CrossRef] [PubMed]

19. Favez, O.; El Haddad, I.; Piot, C.; Boréave, A.; Abidi, E.; Marchand, N.; Jaffrezo, J.-L.; Besombes, J.-L.; Personnaz, M.-B.; Sciare, J.; et al. Inter-comparison of source apportionment models for the estimation of wood burning aerosols during wintertime in an Alpine city (Grenoble, France). Atmos. Chem. Phys. 2010, 10, 5295-5314. [CrossRef]

20. Massabò, D.; Caponi, L.; Bernardoni, V.; Bove, M.C.; Brotto, P.; Calzolai, G.; Cassola, F.; Chiari, M.; Fedi, M.E.; Fermo, P.; et al. Multi-wavelength optical determination of black and brown carbon in atmospheric aerosols. Atmos. Environ. 2015, 108, 1-12. [CrossRef]

21. Ajtai, T.; Utry, N.; Pintér, M.; Major, B.; Bozóki, Z.; Szabó, G. A method for segregating the optical absorption properties and the mass concentration of winter time urban aerosol. Atmos. Environ. 2015, 122, 313-320. [CrossRef]

22. Dinar, E.; Riziq, A.A.; Spindler, C.; Erlick, C.; Kiss, G.; Rudich, Y. The complex refractive index of atmospheric and model humic-like substances (HULIS) retrieved by a cavity ring down aerosol spectrometer (CRD-AS). Faraday Discuss. 2008, 137, 279-295. [CrossRef] [PubMed] 
23. Martinsson, J.; Eriksson, A.C.; Elbæk Nielsen, I.; Berg Malmborg, V.; Ahlberg, E.; Andersen, C.; Lindgren, R.; Nyström, R.; Nordin, E.Z.; Brune, W.H.; et al. Impacts of Combustion Conditions and Photochemical Processing on the Light Absorption of Biomass Combustion Aerosol. Environ. Sci. Technol. 2015, 49, 14663-14671. [CrossRef] [PubMed]

24. Jo, D.S.; Park, R.J.; Lee, S.; Kim, S.-W.; Zhang, X. A global simulation of brown carbon: Implications for photochemistry and direct radiative effect. Atmos. Chem. Phys. 2016, 16, 3413-3432. [CrossRef]

25. Kirchstetter, T.W.; Novakov, T.; Hobbs, P.V. Evidence that the spectral dependence of light absorption by aerosols is affected by organic carbon. J. Geophys. Res. 2004, 109, D21208. [CrossRef]

26. Sun, H.; Biedermann, L.; Bond, T.C. Color of brown carbon: A model for ultraviolet and visible light absorption by organic carbon aerosol. Geophys. Res. Lett. 2007, 34, L17813. [CrossRef]

27. Cheng, Y.; He, K.-B.; Zheng, M.; Duan, F.-K.; Du, Z.-Y.; Ma, Y.-L.; Tan, J.-H.; Yang, F.-M.; Liu, J.-M.; Zhang, X.-L.; et al. Mass absorption efficiency of elemental carbon and water-soluble organic carbon in Beijing, China. Atmos. Chem. Phys. 2011, 11, 11497-11510. [CrossRef]

28. Liu, J.; Bergin, M.; Guo, H.; King, L.; Kotra, N.; Edgerton, E.; Weber, R.J. Size-resolved measurements of brown carbon in water and methanol extracts and estimates of their contribution to ambient fine-particle light absorption. Atmos. Chem. Phys. 2013, 13, 12389-12404. [CrossRef]

29. Zhang, X.; Lin, Y.-H.; Surratt, J.D.; Weber, R.J. Sources, Composition and Absorption Ångström Exponent of Light-absorbing Organic Components in Aerosol Extracts from the Los Angeles Basin. Environ. Sci. Technol. 2013, 47, 3685-3693. [CrossRef] [PubMed]

30. Kim, H.; Kim, J.Y.; Jin, H.C.; Lee, J.Y.; Lee, S.P. Seasonal variations in the light-absorbing properties of water-soluble and insoluble organic aerosols in Seoul, Korea. Atmos. Environ. 2016, 129, 234-242. [CrossRef]

31. Cheng, Y.; He, K.; Engling, G.; Weber, R.; Liu, J.; Due, Z.; Dong, S. Brown and black carbon in Beijing aerosol: Implications for the effects of brown coating on light absorption by black carbon. Sci. Total Environ. 2017, 599-600, 1047-1055. [CrossRef] [PubMed]

32. Bohren, C.F.; Huffmann, D.R. Absorption and Scattering by Small Particles; John Wiley \& Sons: New York, NY, USA, 1983; ISBN 0-471-05772-X.

33. Massabò, D.; Bernardoni, V.; Bove, M.C.; Brunengo, A.; Cuccia, E.; Piazzalunga, A.; Prati, P.; Valli, G.; Vecchi, R. A multi-wavelength optical set-up for the characterization of carbonaceous particulate matter. J. Aerosol Sci. 2013, 60, 34-46. [CrossRef]

34. Vecchi, R.; Bernardoni, V.; Paganelli, C.; Valli, G. A filter-based light-absorption measurement with polar photometer: Effects of sampling artefacts from organic carbon. J. Aerosol Sci. 2014, 70, 15-25. [CrossRef]

35. Bernardoni, V.; Valli, G.; Vecchi, R. Set-up of a multi wavelength polar photometer for off-line absorption coefficient measurements on 1-h resolved aerosol samples. J. Aerosol Sci. 2017, 107, 84-93. [CrossRef]

36. Weingartner, E.; Saathoff, H.; Schnaiter, M.; Streit, N.; Bitnar, B.; Baltensperger, U. Absorption of light by soot particles: Determination of the absorption coefficient by means of aethalometers. J. Aerosol Sci. 2003, 34, 1445-1463. [CrossRef]

37. Subramanian, R.; Roden, C.A.; Boparai, P.; Bond, T.C. Yellow Beads and Missing Particles: Trouble Ahead for Filter-Based Absorption Measurements. Aerosol Sci. Technol. 2007, 41, 630-637. [CrossRef]

38. Massabò, D.; Caponi, L.; Bove, M.C.; Prati, P. Brown carbon and thermal-optical analysis: A correction based on optical multi-wavelength apportionment of atmospheric aerosols. Atmos. Environ. 2016, 125, 119-125. [CrossRef]

39. Amato, F.; Alastuey, A.; Karanasiou, A.; Lucarelli, F.; Nava, S.; Calzolai, G.; Severi, M.; Becagli, S.; Gianelle, V.L.; Colombi, C.; et al. AIRUSE-LIFE+: A harmonized PM speciation and source apportionment in five southern European cities. Atmos. Chem. Phys. 2016, 16, 3289-3309. [CrossRef]

40. Bernardoni, V.; Vecchi, R.; Valli, G.; Piazzalunga, A.; Fermo, P. PM10 source apportionment in Milan (Italy) using time-resolved data. Sci. Total Environ. 2011, 409, 4788-4795. [CrossRef] [PubMed]

41. Bernardoni, V.; Calzolai, G.; Chiari, M.; Fedi, M.; Lucarelli, F.; Nava, S.; Piazzalunga, A.; Riccobono, F.; Taccetti, F.; Valli, G.; et al. Radiocarbon analysis on organic and elemental carbon in aerosol samples and source apportionment at an urban site in Northern Italy. J. Aerosol Sci. 2013, 56, 88-99. [CrossRef]

42. Vecchi, R.; Bernardoni, V.; Fermo, P.; Piazzalunga, A.; Valentini, S.; Valli, G. Assessment of light extinction at a European polluted urban area during wintertime: Impact of PM1 composition and sources. Environ. Pollut. 2018, 233, 679-689. [CrossRef] [PubMed] 
43. Bernardoni, V.; Cuccia, E.; Calzolai, G.; Chiari, M.; Lucarelli, F.; Massabò, D.; Nava, S.; Prati, P.; Valli, G.; Vecchi, R. ED-XRF set-up for size-segregated aerosol samples analysis. X-Ray Spectrom. 2011, 40, $79-87$. [CrossRef]

44. Bernardoni, V.; Elser, M.; Valli, G.; Valentini, S.; Bigi, A.; Fermo, P.; Piazzalunga, A.; Vecchi, R. Size-segregated aerosol in a hot-spot pollution urban area: Chemical composition and three-way source apportionment. Environ. Pollut. 2017, 231, 601-611. [CrossRef] [PubMed]

45. Hänel, G. Radiation budget of the boundary layer: Part II. Simultaneous measurement of mean solar volume absorption and extinction coefficients of particles. Beitr. Phys. Atmos. 1987, 60, 241-247.

46. Hänel, G. Optical properties of atmospheric particles: Complete parameter sets obtained through polar photometry and an improved inversion technique. Appl. Opt. 1994, 33, 7187-7199. [CrossRef] [PubMed]

47. Petzold, A.; Schönlinner, M. Multi-angle absorption photometry-A new method for the measurement of aerosol light absorption and atmospheric black carbon. J. Aerosol Sci. 2004, 35, 421-441. [CrossRef]

48. Piazzalunga, A.; Fermo, P.; Bernardoni, V.; Vecchi, R.; Valli, G.; De Gregorio, M.A. A simplified method for levoglucosan quantification in wintertime atmospheric particulate matter by high performance anion-exchange chromatography coupled with pulsed amperometric detection. Int. J. Environ. Anal. Chem. 2010, 90, 934-947. [CrossRef]

49. Cavalli, F.; Putaud, J.P.; Viana, M.; Yttri, K.E.; Gemberg, J. Toward a standardized thermal-optical protocol for measuring atmospheric organic and elemental carbon: The EUSAAR protocol. Atmos. Meas. Tech. 2010, 3, 79-89. [CrossRef]

50. Piazzalunga, A.; Bernardoni, V.; Fermo, P.; Valli, G.; Vecchi, R. Technical note: On the effect of water-soluble compounds removal on EC quantification by TOT analysis in urban aerosol samples. Atmos. Chem. Phys. 2011, 11, 10193-10203. [CrossRef]

51. Olson, M.R.; Victoria Garcia, M.; Robinson, M.A.; Van Rooy, P.; Dietenberger, M.A.; Bergin, M.; Schauer, J.J. Investigation of black and brown carbon multiple-wavelength-dependent light absorption from biomass and fossil fuel combustion source emissions. J. Geophys. Res. Atmos. 2015, 120, 6682-6697. [CrossRef]

52. Gyawali, M.; Arnott, W.P.; Lewis, K.; Moosmüller, H. In situ aerosol optics in Reno, NV, USA during and after the summer 2008 California wildfires and the influence of absorbing and non-absorbing organic coatings on spectral light absorption. Atmos. Chem. Phys. 2009, 9, 8007-8015. [CrossRef]

53. Zotter, P.; Herich, H.; Gysel, M.; El-Haddad, I.; Zhang, Y.; Močnik, G.; Hüglin, C.; Baltensperger, U.; Szidat, S.; Prévôt, A.S.H. Evaluation of the absorption Ångström exponents for traffic and wood burning in the Aethalometer-based source apportionment using radiocarbon measurements of ambient aerosol. Atmos. Chem. Phys. 2017, 17, 4229-4249. [CrossRef]

54. Bond, T.C.; Bergstrom, R.W. Light absorption by carbonaceous particles: An investigative review. Aerosol Sci. Technol. 2006, 40, 27-67. [CrossRef]

55. Moosmüller, H.; Chakrabarty, R.K.; Ehlers, K.M.; Arnott, W.P. Absorption Ångström coefficient, brown carbon, and aerosols: Basic concepts, bulk matter, and spherical particles. Atmos. Chem. Phys. 2011, 11, 1217-1225. [CrossRef]

56. Martinsson, J.; Abdul Azeem, H.; Sporre, M.K.; Bergström, R.; Ahlberg, E.; Öström, E.; Kristensson, A.; Swietlicki, E.; Eriksson Stenström, K. Carbonaceous aerosol source apportionment using the Aethalometer model-Evaluation by radiocarbon and levoglucosan analysis at a rural background site in southern Sweden. Atmos. Chem. Phys. 2017, 17, 4265-4281. [CrossRef]

57. Harrison, R.M.; Beddows, D.C.S.; Jones, A.M.; Calvo, A.; Alves, C.; Pio, C. An evaluation of some issues regarding the use of aethalometers to measure woodsmoke concentrations. Atmos. Environ. 2013, 80, 540-548. [CrossRef]

58. Titos, G.; del Ãguila, A.; Cazorla, A.; Lyamani, H.; Casquero-Vera, J.A.; Colombi, C.; Cuccia, E.; Gianelle, V.; Močnik, G.; Alastuey, A.; et al. Spatial and temporal variability of carbonaceous aerosols: Assessing the impact of biomass burning in the urban environment. Sci. Total Environ. 2017, 578, 613-625. [CrossRef] [PubMed]

59. Petzold, A.; Ogren, J.A.; Fiebig, M.; Laj, P.; Li, S.-M.; Baltensperger, U.; Holzer-Popp, T.; Kinne, S.; Pappalardo, G.; Sugimoto, N.; et al. Recommendations for reporting "black carbon" measurements. Atmos. Chem. Phys. 2013, 13, 8365-8379. [CrossRef] 
60. Utry, N.; Ajtai, T.; Pintér, M.; Tombácz, E.; Illés, E.; Bozóki, Z.; Szabó, G. Mass-specific optical absorption coefficients and imaginary part of the complex refractive indices of mineral dust components measured by a multi-wavelength photoacoustic spectrometer. Atmos. Meas. Tech. 2015, 8, 401-410. [CrossRef]

61. Lack, D.A.; Langridge, J.M. On the attribution of black and brown carbon light absorption using the Ångstrom exponent. Atmos. Chem. Phys. 2013, 13, 10535-10543. [CrossRef]

62. Szidat, S.; Jenk, T.M.; Synal, H.-A.; Kalberer, M.; Wacker, L.; Hajdas, I.; Kasper-Giebl, A.; Baltensperger, U. Contributions of fossil fuel, biomass-burning, and biogenic emissions to carbonaceous aerosols in Zurich as traced by ${ }^{14}$ C. J. Geophys. Res. 2006, 111, D07206. [CrossRef]

63. Piazzalunga, A.; Belis, C.; Bernardoni, V.; Cazzuli, O.; Fermo, P.; Valli, G.; Vecchi, R. Estimates of wood burning contribution to PM by the macro-tracer method using tailored emission factors. Atmos. Environ. 2011, 45, 6642-6649. [CrossRef]

64. Minguillón, M.C.; Perron, N.; Querol, X.; Szidat, S.; Fahrni, S.M.; Alastuey, A.; Jimenez, J.L.; Mohr, C.; Ortega, A.M.; Day, D.A.; Lanz, V.A.; et al. Fossil versus contemporary sources of fine elemental and organic carbonaceous particulate matter during the DAURE campaign in Northeast Spain. Atmos. Chem. Phys. 2011, 11, 12067-12084. [CrossRef]

65. Pio, C.; Cerqueira, M.; Harrison, R.M.; Nunes, T.; Mirante, F.; Alves, C.; Oliveira, C.; Sanchez de la Campa, A.; Artínano, B.; Matose, M. OC/EC ratio observations in Europe: Re-thinking the approach for apportionment between primary and secondary organic carbon. Atmos. Environ. 2011, 45, 6121-6132. [CrossRef]

66. Grieshop, A.P.; Logue, J.M.; Donahue, N.M.; Robinson, A.L. Laboratory investigation of photochemical oxidation of organic aerosol from wood fires 1: Measurement and simulation of organic aerosol evolution. Atmos. Chem. Phys. 2009, 9, 1263-1277. [CrossRef]

67. Lanz, V.A.; Alfarra, R.; Baltensperger, U.; Buchmann, B.; Hueglin, C.; Szidat, S.; Wehrli, M.N.; Wacker, L.; Weimer, S.; Caseiro, A.; et al. Source attribution of submicron organic aerosols during wintertime inversions by advanced factor analysis of aerosol mass spectra. Environ. Sci. Technol. 2008, 42, 214-220. [CrossRef] [PubMed]

68. Vecchi, R.; Marcazzan, G.; Valli, G.; Ceriani, M.; Antoniazzi, C. The role of atmospheric dispersion in the seasonal variation of PM1 and PM2.5 concentration and composition in the urban area of Milan (Italy). Atmos. Environ. 2004, 38, 4437-4446. [CrossRef]

69. Vecchi, R.; Marcazzan, G.; Valli, G. Seasonal variation of ${ }^{21}{ }^{\circ} \mathrm{Pb}$ activity concentration in outdoor air of Milan (Italy). J. Environ. Radioact. 2005, 82, 251-266. [CrossRef] [PubMed]

70. Zanatta, M.; Gysel, M.; Bukowiecki, N.; Müller, T.; Weingartner, E.; Areskoug, H.; Fiebig, M.; Yttri, K.E.; Mihalopoulos, N.; Kouvarakis, G.; et al. European aerosol phenomenology-5: Climatology of black carbon optical properties at 9 regional background sites across Europe. Atmos. Environ. 2016, 145, 346-364. [CrossRef]

(c) 2017 by the authors. Licensee MDPI, Basel, Switzerland. This article is an open access article distributed under the terms and conditions of the Creative Commons Attribution (CC BY) license (http://creativecommons.org/licenses/by/4.0/). 